JIKAP PGSD: Jurnal Ilmiah Ilmu Kependidikan

Vol, 4. No,1. Tahun 2020

e-ISSN: 2597-4440 dan p-ISSN: 2597-4424

This work is licensed under a Creative Commons Attribution

4.0 International License

\title{
Kinerja Guru Kelas Dalam Menyusun dan Mengembangkan Perangkat Pembelajaran di SD Negeri KIP Maccini Makassar
}

\author{
Nurul Hikmah ${ }^{1}$, Syarifuddin Cn Sida ${ }^{2}$, Idawati ${ }^{3}$ \\ ${ }^{1,2,3}$ Pendidikan Dasar, Program Pascasarjana Universitas Muhammadiyah Makassar \\ E-mail: ${ }^{1}$ nunu.mks0330@ gmail.com \\ ${ }^{2}$ Syarifuddin.sida@gmail.com \\ 3idawati@gmail.com
}

\begin{abstract}
Abstrak. Penelitian ini bertujuan untuk mengkaji kinerja guru kelas dalam menyusun dan mengembangkan perangkat pembelajaran di SD Negeri KIP Maccini Makassar. Jenis penelitian ini menggunakan metode penelitian deskriptif kualitatif. Lokasi dalam penelitian ini adalah SD Negeri KIP Maccini Makassar. Jenis data dalam penelitian ini adalah data primer yang diperoleh langsung dari informan dan data sekunder berupa dokumen-dokumen yang berhubungan dengan permasalahan dan laporan-laporan penelitian. Instrumen dalam penelitian ini adalah peneliti sendiri dan alat pengumpulan data penunjang berupa pedoman wawancara. Berdasarkan hasil penelitian bahwa kinerja guru bersertifikat pendidik SDN KIP MACCINI dalam perencanaan pembelajaran mendapatkan rata-rata skor yaitu sebesar 18,32 masuk dalam kategori Cukup Efektif. Hasil penilaian ini menunjukkan bahwa guru bersertifikat pendidik SDN KIP MACCINI sudah cukup baik kinerjanya dalam perencanaan pembelajaran.
\end{abstract}

Kata kunci: Kinerja guru, Perangkat pembelajaran

\begin{abstract}
This study aims to study the performance of the teachers in developing and expanding learning devices in the state SDN KIP Maccini Makassar. This type of research uses qualitative descriptive research methods. The location in this research is the state elementary school KIP Maccini Makassar. The types of data in this study are primary data obtained directly from the informant and secondary data in the form of documents relating to the issues and the research reports. The instruments in this research are own researchers and supporting data collection tools are interview guidelines. Based on the results of the study that the performance of teachers certified by SDN KIP MACCINI in the planning of learning received an average score of 18.32 in the category quite effective. The assessment showed that teachers certified by SDN KIP MACCINI were well-performing in the planning of learning.
\end{abstract}

Keywords: Teacher performance, Learning devices

\section{PENDAHULUAN}

Guru merupakan salah satu tenaga kependidikan yang mempunyai peran penting sebagai faktor penentu keberhasilan tujuan organisasi dan mutu pendidikan Kasih diakhir teks, sebelum referensi. Kinerja guru harus selalu ditingkatkan mengingat tantangan dunia pendidikan untuk menghasilkan kualitas sumber daya manusia mampu bersaing di era global semakin meningkat.

Undang-undang Nomor 14 tahun 2005 tentang Guru dan Dosen, pada Pasal 1 ayat (1) 
menjelaskan bahwa Guru adalah pendidik profesional dengan tugas utama mendidik, mengajar, membimbing, mengarahkan, melatih, menilai dan mengevaluasi peserta didik pada pendidikan anak usia dini jalur pendidikan formal, pendidikan dasar dan pendidikan menengah.

Soetjipto dan Raflis Kosasi (1994) menyatakan bahwa kualitas proses belajar mengajar sangat dipengaruhi oleh kualitas kinerja guru. Artinya, kualitas kinerja guru akan sangat menentukan keberhasilan suatu pembelajaran yang akan berpengaruh pada kualitas hasil pendidikan. Oleh karena itu, salah satu upaya untuk meningkatkan kualitas kinerja guru adalah kemampuan dalam merencanakan pembelajaran yaitu dengan meningkatkan kemampuan dalam menyusun maupun mengembangkan perangkat pembelajaran (Sommeng, 2019)

Tuntutan pada guru berkaitan dengan kemampuan dalam menyusun dan mengembangkan perancanaan pembelajaran dapat dilihat pada Permendikbud Nomor 22 tahun 2016 tentang Pedoman Penyusunan RPP, dalam Permendikbud tersebut mengisyaratkan adanya standar guru dalam menyusun dan mengembangkan perencanaan pembelajaran, selanjutnya dipertegas melalui Permendikbud Nomor 20 tahun 2016 tentang Standar Kompetensi Kelulusan Pendidikan Dasar dan Menengah, Permendikbud Nomor 21 Tahun 2016 tentang Standar Isi Satuan Pendidikan Dasar dan Menengah, Permendikbud Nomor 23 Tahun 2016 tentang Standar Penilaian.

Pada hakikatnya perangkat pembelajaran penyusunan RPP bertujuan merancang pengalaman belajar peserta didik untuk mencapai tujuan pembelajaran. Menurut Mulyana (2012) alasan pentingnya menyusun perangkat pembelajaran RPP yaitu menolong guru untuk memikirkan pelajaran sebelum pelajaran itu diajarkan sehingga kesulitan belajar dapat diramalkan dan jalan keluarnya dapat ditemukan.

Keberhasilan dari tujuan pendidikan ditentukan bagaimana silabus dan RPP diimplementasikan pada suatu pendidikan, dalam bentuk kegiatan pembelajaran serta pada satuan pendidikan, dalam bentuk kegiatan pembelajaran dan pada desain atau rencana pembelajaran yang telah ditetapkan. Secara umum dalam proses pembelajaran seringkali tanpa didukung dengan pelaksanaan pembelajaran RPP yang baik, pelaksanaan pembelajaran yang dilakukan tanpa persiapan dari guru menjadikan proses pembelajaran yang tidak dapat diterima dan tidak menarik bahkan tidak menyenangkan bagi peserta didik, kedatangan guru tidak tepat waktu, meninggalkan kelas sebelum waktunya, kegiatan penilaian yang tidak terorganisir dengan baik sehingga hasil evaluasi tidak tercapai.

SD Negeri KIP Maccini merupakan salah satu sekolah yang terletak di Kecamatan Makassar, pada saat calon peneliti melakukan observasi awal pada hari Jum'at tanggal 11 Januari 2018, dari 12 guru kelas di SD Negeri KIP Maccini masih ada 2 guru yang masih kesulitan dalam menyusun dan mengembangkan perangkat pembelajaran seperti RPP yang salah satu penyebabnya adalah kemalasan dari guru dalam menyusun dan mengembangkan perangkat pembelajaran RPP. Hal ini disebabkan karena adanya kemudahan-kemudahan dari aplikasi yang dengan mudah diakses melalui media elektronik atau internet sehingga yang terjadi adalah guru hanya menggandakan file kemudian memindahkan file dan hanya mengganti pada bagian-bagian tertentu dengan menyesuaikannya pada standar kompetensi. Jelas bahwa hal ini membuat ketidakseriusan guru dalam menyusun dan mengembangkan perangkat pembelajaran.

Sesuai dengan landasan dasar hukum guru harus membuat RPP, berdasarkan Peraturan Pemerintah Nomor 32 Tahun 2013 tentang Standar Nasional Pendidikan, bahwa setiap guru pada satuan pendidikan berkejawiban menyusun RPP secara lengkap dan sistematis. Bagi guru yang ingin mengembangkan profesionalismenya sudah sewajarnya guru harus memahami tentang Standar Proses Pendidikan dan Standar Penilaian Pendidikan yang berlaku sesuai dengan kurikulum yang digunakan.

\section{METODE PENELITIAN}

Pada penelitian ini menggunakan metode penelitian deskriptif kualitatif. Penelitian ini dilakukan dengan mengamati subjek dan objek penelitian berdasarkan fakta-fakta yang ada. Fakta yang ditemukan dideskripsikan secara mendalam. Dalam penelitian ini, dimana peneliti menggambarkan secara kongkrit dan mendalam secara alami dilapangan sehingga memberikan pemahaman yang senyatanya artinya penelitian ini tidak dapat diwakilkan.

Penelitian ini berlokasi di SD Negeri KIP Maccini Makassar. Tepatnya dikecamatan Ujung Tanah kelurahan Maccini Raya Jalan 
Abubakar Lambogo. Fokus penelitian merupakan pokok persoalan yang menjadi pusat perhatian dalam penelitian. Fokus penelitian ini adalah tentang kinerja guru sebagai indikator dari fokus tersebut adalah Kinerja guru, faktor yang mendukung kinerja guru, dan faktor yang menghambat kinerja guru dalam menyusun dan mengembangkan perangkat pembelajaran di SD Negeri KIP Maccini Makassar.

Instrumen utama dalam penelitian ini adalah peneliti, karena peneliti adalah manusia dan hanya manusia yang dapat berhubungan dengan responden atau objek lainnya, serta mampu memahami kaitan kenyataan-kenyataan di lapangan. Oleh karena itu, peneliti juga berperan serta dalam melalukan pengataman terhadap objek fokus penelitian. Sedangkan alat pengumpulan data penunjang adalah pedoman wawancara berupa daftar pertanyaan, catatan lapangan dan rekaman tape recorder.

Kegiatan yang dilakukan oleh peneliti untuk mengamati kegiatan guru secara langsung dalam menyusun dan mengembangkan perangkat pembelajaran disekolah yang dilakukan oleh informan (guru). Dalam hal ini, untuk melakukan pengumpulan data peneliti menggunakan observasi terus terang kepada sumber data, bahwa ia sedang melakukan penelitian. Jadi informan akan mengetahui sejak awal sampai akhir tentang aktivitas peneliti. Sehingga Peneliti akan turun langsung kelokasi penelitian untuk mengambil data mengenai kinerja guru kelas dalam menyusun dan mengembangkan perangkat pembelajaran di SD Negeri KIP Maccini Makassar, dan melihat kinerja guru dalam membuat dan menyusun perangkat pembelajaran, membuat materi ajar, membuat media pembelajaran, lembar kerja peserta didik sampai dengan membuat penilaian. Wawancara adalah kegiatan tanya jawab secara langsung yang dilakukan oleh peneliti kepada informan (guru) yang bertugas dalam lingkup sekolah di SD Negeri KIP Maccini Makassar. Wawancara ini dilakukan agar dapat mendapat jawaban dari permasalahan yang akan diteliti oleh peneliti, sehingga peneliti mengajukan beberapa daftar pertanyaan yang berhubungan dengan permasalahan yang akan diteliti kepada guru dan agar datanya lebih kuat peneliti juga melakukan wawancara kepada kepala sekolah.

Dokumentasi adalah cara pengumpulan data dengan mencari data dari catatan-catatan, buku-buku tentang pendapat, teori dan bukti. Maksudnya adalah dalam mendapatkan data-data dengan cara kepustakaan yaitu mengumpulkan, membaca dan mempelajari buku-buku (literatul) yang ada hubungannya dengan masalah yang akan dibahas. Dokumentasi dalam penelitian ini bertujuan untuk memperoleh data melalui pengurus tata usaha sekolah setempat dan dokumen tentang kegiatan guru dan mendokumentasikan hasil kerja guru saat menyusun dan mengembangkan perangkat pembelajaran apa sesuai dengan standar kompetensi yang telah ditentukan satuan pendidikan.

\section{HASIL DAN PEMBAHASAN}

Berdasarkan data observasi menunjukkan bahwa kinerja guru dalam menyusun dan mengembangkan perangkat pembelajaran disekolah sudah cukup maksimal, karena data yang di peroleh peneliti pada saat melakukan observasi menunjukkan bahwa $90 \%$ guru telah menyusun dan mengembangkan perangkat pembelajaran sesuai dengan sistematika yang telah ditentukan didalam satuan pendidikan Permendikbud Nomor 22 Tahun 2016.

Guru yang mengalami kesulitan dalam menyusun dan mengembangkan perangkat pembelajaran, hal yang mereka lakukan adalah melakukan diskusi sesama rekan guru ataupun sesama rekan-rekan guru lainnya. Selain pada saat melakukan pelatihan Diklat (PLPG) mereka juga mendiskusikan atau meminta solusi terhadap kendala yang dihadapi pada saat menyusun dan mengembangkan perangkat pembelajaran kepada pengawas PLPG saat melakukan pelatihan Diklat.

Menurut pendapat dari Husdarta, Kinerja guru dalam pembelajaran menjadi bagaian terpenting dalam mendukung terciptanya proses pendidikan secara efektif terutama dalam membangun sikap disiplin dan mutu hasil belajar siswa. Dengan demikian, guru sangat menentukan mutu pendidikan, berhasil tidaknya proses pembelajaran, tecapai tidaknya tujuan pendidikan dan pembelajaran, terorganisasikannya sarana prasarana, peserta didik, media, alat dan sumber belajar. Kinerja guru yang baik dapat menciptakan efektivitas dan efisiensi pembelajaran serta dapat membentuk disiplin peserta didik, madrasah dan guru sendiri. Kinerja guru merupakan kemampuan seorang guru dalam melaksanakan tugas pembelajaran di sekolah dan bertanggung jawab atas peserta didik di bawah bimbingannya dan meningkatkan prestasi belajar didik. Oleh karena itu, kinerja guru itu dapat diartikan 
sebagai kondisi yang menunjukkan kemampuan seorang guru dalam menjalankan tugasnya di sekolah serta menggambarkan adanya suatu perbuatan yang ditampilkan guru dalam atau selama melakukan aktivitas pembelajaran. Kinerja guru tidak hanya ditunjukkan oleh hasil kerja, akan tetapi juga ditunjukkan oleh perilaku dalam bekerja.

Berdasarkan pengamatan dan dokumentasi yang dilakukan terhadap empat guru mata pelajaran produktif dengan menganalisis RPP yang dirancang oleh guru kelas SDN KIP MACCINI KOTA MAKASSAR pada umumnya bervariasi bentuk penyusunan dan cenderung hanya dibuat untuk memenuhi standar pengumpulan administrasi tanpa melihat arti penting RPP sebagai pedoman dalam pembelajaran.

RPP sekurang-kurangnya memuat bagaimana guru menyusun materi pembelajaran, tujuan pembelajaran, metode pembelajaran, media dan sumber belajar, perencanaan langkah-langkah pembelajaran serta perancangan tes dan tugas-tugas.

RPP yang dibuat oleh guru sama untuk setiap kali pertemuan, seperti halnya untuk metode tidak melihat dari teori yang sedang diajarkan. Selain itu masih terdapat beberapa guru yang tidak menerapkan pembelajaran sesuai dengan RPP diantaranya: belum menggunakan metode, media maupun sumber belajar yang bervariasi. Guru cenderung hanya mengacu pada buku paket dan lembar kerja siswa sebagai sumber belajar. Hal ini mengindikasikan bahwa guru belum mampu menyusun RPP dengan baik serta menggunakan metode, media dan sumber belajar secara optimal.

\section{SIMPULAN DAN SARAN}

Hasil penilaian terhadap kinerja guru bersertifikat pendidik SDN KIP MACCINI dalam perencanaan pembelajaran mendapatkan rata-rata skor yaitu sebesar 18,32 masuk dalam kategori Cukup Efektif. Hasil penilaian ini menunjukkan bahwa guru bersertifikat pendidik SDN KIP MACCINI sudah cukup baik kinerjanya dalam perencanaan pembelajaran.

Institusi pendidikan dalam hal ini SDN KIP Maccini perlu mengadakan audit kinerja guru bersertifikat pendidik ini secara berkelanjutan yang mengacu pada pelaksanaan tugas pokok dan fungsi guru bersertifikat pendidik di sekolah, sehingga mampu meningkatkan motivasi kerja guru bersertifikat pendidik dan dapat memberikan masukan untuk perencanaan sumber daya manusia guru di SDN KIP MACCINI.

\section{DAFTAR RUJUKAN}

Barnawi, Mohammad Arifin. 2014. Kinerja Guru Profesional. Yogyakarta: Ar- Ruzz Media.

Dimyati dan Mudjiono. 1999. Belajar dan Pembelajaran. Jakarta: Rineka Cipta.

Donni Juni Priansa. 2014. Kinerja dan Profesionalisme Guru. Bandung:. CV.Alfabeta.

Gaffar. 2005. Profesionalisasi Pendidik dan Tenaga Kependidikan. Bandung.

Glasman, N.S. 1986. Evaluated-Based Leadership: school Administration in Contemporary Perspective. New York: State University of New York Pres.

Hakim. 2009. Perencanaan Pembelajaran. Bandung: CV. Wacana Prima.

Husdarta, J.S. Faktor-faktor yang Mempengaruhi Kinerja Guru Pendidikan Jasmani di Sekolah Dasar. Jurnal Mimbar Pendidikan, 26 (3).

Moleong, Lexy J. 2010. Metodologi Penelitian Kualitatif. Bandung: PT Remaja Rosdakarya.

Mulyana. 2012. Ilmu Komunikasi Suatu Pengajaran. Bandung: PT. Remaja Rosdakarya.

Mulyasa, 2005. Menjadi Guru Profesional Menciptakan Pembelajaran Kreatif dan Menyenangkan. Bandung: Rosdakarya.

Munandar, SC. 1992. Mengembangkan Bakat Anak. Jakarta: Gramedia.

Murgatroyd, S. and Morgan, M.1993. Total Quality Management and The School. Philadelphia: Open University Press.

Riva'i. 2004. Manajemen Sumber Daya Manusia Untuk Perusahaan. Jakarta: Murai Kencana.

Pidarta, M. 1995. Peranan Kepala Sekolah Pada Pendidikan Dasar, Jakarta: Gramedia.

Slavin, RE. 1994. Cooperative Learning: Theory, Research and Practice. Englewood Cliff, NJ: Prentice Hall.

Soetjipto dan Kosasih, R. 1994. Profesi Keguruan. Jakarta: Ditjen Dikti.

Sommeng, A. 2019. Peningkatan Kemampuan Guru dalam Pengembangan Silabus dan RPP Melalui Pola Pembinaan Profesional dengan Pendekatan Kooperatif. JIKAP PGSD: Jurnal Ilmiah 
Ilmu Kependidikan, 3 (3): 263-273

DOI: http://doi.org/10.26858/jkp.v3i3. 10230

Supardi. 2014. Kinerja Guru. Jakarta: PT. Raja Grafindo Persada.

Tempe.1992. Kinerja. Jakarta: PT Eleax Media Komputindo.

Trianto. 2007. Model-model Pembelajaran Inovatif Berorientasi Kontruktivistik. Jakarta: Prestasi Pustaka

Usman. 2002. Menjadi Guru Profesional. Bandung: PT Remaja Rosdakarya.

Zuhdan. 2011. Pengembangan Perangkat Pembelajaran Sains Terpadu Untuk Meningkatkan Kognitif. Yogyakarta: Program Pascasarjana UNY. 